\title{
Renal Response to Chronic Intravenous Salt Loading in the Rat
}

\author{
Terrance M. Daugharty, Irus F. Uekt, Delys P. Nicholas, and \\ BARRY M. BRENNER \\ From the Departments of Medicine, Veterans Administration Hospital, \\ San Francisco, California 94121 and the University of California, \\ San Francisco, California 94122
}

\begin{abstract}
A BSTRACT The natriuresis of acute Ringer's loading is associated with a rise in the rate of delivery of fluid beyond the proximal tubule due both to a rise in glomerular filtration and a fall in absolute reabsorption, the latter being causally mediated, at least in part, by the accompanying fall in postglomerular vascular [protein]. To determine whether these factors also contribute to the renal response to chronic Ringer's loading, nine rats given continuous infusions, $30 \%$ body weight/ day over 5-14 days, were studied using free-flow micropuncture techniques. Results were compared with data from 10 chronic control rats given less than $1.5 \%$ body wt/day. Late proximal tubule fluid-to-plasma [inulin] ratios, $(T F / P) r$, single nephron glomerular filtration rate (SNGFR), absolute proximal reabsorption, and postglomerular vascular [protein] in chronic control rats and chronically loaded rats averaged $2.2 \pm \mathrm{SE} 0.1$ $(\mathrm{n}=35)$ and $1.5 \pm 0$ (35), $P<0.001 ; 37 \pm 2(35)$ and $47 \pm 4 \mathrm{nl} / \mathrm{min}(35), P<0.05 ; 19 \pm 1$ (35) and $16 \pm 2$ $\mathrm{nl} / \mathrm{min}(35), P>0.2$; and $9.5 \pm 0.3$ (8) and $8.6 \pm 0.3$ $\mathrm{g} / 100 \mathrm{ml}$ (8), $P>0.05$, respectively. Thus the fall in $(\mathrm{TF} / \mathrm{P})_{\mathrm{IN}}$ and the rise in distal delivery during chronic Ringer's loading were due almost entirely to the rise in SNGFR, and not to any large fall in absolute reabsorption. Hence chronic and acute Ringer's loading increase delivery of proximal tubule fluid by different mechanisms, with chronic sodium homeostasis being governed overwhelmingly by adjustments in GFR.
\end{abstract}

This work was presented in part at the National Meeting of the American Society of Nephrology, Washington, D. C., 23 November 1971.

Dr. Daugharty's work was performed as a Research and - Education Associate of the Veterans Administration. Dr. Brenner is a Medical Investigator of the Veterans Administration.

Received for publication 30 March 1972 and in revised form 5 September 1972.
When, however, an acute Ringer's load was infused into chronically loaded rats, we observed significant and parallel reductions in absolute proximal reabsorption and postglomerular vascular [protein]. These findings suggest that the difference between the effects of chronic vs. acute Ringer's loading on absolute proximal reabsorption may have been due, at least in part, to the corresponding difference in the effects these two loading procedures have on postglomerular vascular [protein].

\section{INTRODUCTION}

There is abundant evidence in the rat to indicate that the natriuresis that attends the acute expansion of extracellular volume with colloid-free solutions is associated with an increase in the rate of delivery of proximal tubule fluid to more distal segments of the nephron, an effect due both to a rise in glomerular filtration rate $(G F R)^{1}$ and a fall in absolute proximal reabsorption (1-5). The latter change has been shown to be causally mediated, at least in part, by the accompanying dilutional reduction in postglomerular vascular protein concentration (3). Little is known, however, of the behavior of the proximal nephron during chronic, and, therefore, seemingly more physiologic alterations in extracellular volume. Accordingly, the present study was undertaken to examine the renal response to chronic, continuous intravenous infusions of isotonic, colloid-free Ringer's solution into unanesthetized, freely ambulatory adult rats.

\footnotetext{
${ }^{1}$ Abbreviations used in this paper: AP, mean arterial pressure; GFR, glomerular filtration rate; SNFF, single nephron filtration fraction; SNGFR, single nephron GFR; $(\mathrm{TF} / \mathrm{P})_{\mathrm{IN}}$, late proximal tubule fluid-to-plasma inulin concentration ratio; $\mathrm{U}_{\mathrm{Na}} \mathrm{V}$, sodium excretion.
} 


\section{METHODS}

Chronic control vs. chronically loaded rats. Male SpragueDawley rats weighing 275-414 g and allowed free access to a standard rat pellet diet and water were anesthetized by intraperitoneal injection of the ultrashort-acting barbiturate Brevital sodium, sodium $\alpha-d l-1$-methyl-5-allyl-5-(1methyl-2-pentynyl) barbiturate, $30 \mathrm{mg} / \mathrm{kg}$. An indwelling polyethylene no. 50 catheter was inserted into the right jugular vein for infusion of a modified Ringer's solution containing, in $\mathrm{mM}: \mathrm{NaCl} 115, \mathrm{KCl} 5, \mathrm{NaHCO}_{3} 25$, $\mathrm{NaH}_{2} \mathrm{PO}_{4} 1.2, \mathrm{Na}$ acetate $10, \mathrm{MgSO}_{4} 1.2$, and $\mathrm{CaCl}_{2} 2.5$. Before infusion, venous blood was obtained for base line determination of hematocrit. The venous catheter was brought through a subcutaneous tunnel to the region of the back of the neck where it was exteriorized via a small skin incision. The lengthy external portion of this catheter was threaded through a $25-30 \mathrm{~cm}$ sleeve of protective coiled wire tubing. With this catheter arrangement, continuous intravenous infusions of fluid were administered for periods of up to 14 days without restricting the freedom of mobility of each rat within its cage.

To document and characterize the achievement of a steady state of sodium intake and sodium excretion $\left(\mathrm{U}_{\mathrm{Na}} \mathrm{V}\right)$, in rats receiving Ringer's at the rate of about $30 \%$ body wt/ day $(4.6 \mathrm{ml} / \mathrm{h})$, sodium balances were determined in four rats in the awake state. In these rats, after placement of the infusion catheter and recovery from Brevital anesthesia, quantitative collections of spontaneously voided urine were obtained with the aid of a metabolic cage. Initial control collections were obtained while the animals were receiving Ringer's, $1.2 \mathrm{ml} / \mathrm{h}$; then the rate of infusion was increased to $4.6 \mathrm{ml} / \mathrm{h}$, yielding a rate of sodium infusion of 11.5 $\mu \mathrm{eq} / \mathrm{min}$, and urine collections were obtained until $\mathrm{U}_{\mathrm{Na}} \mathrm{V}$ matched the rate of sodium infusion. Micropuncture studies were not undertaken in these rats.

Nine other chronically loaded rats received continuous intravenous infusions of Ringer's at this same rate of about $30 \%$ body wt/day for periods of from 5 to 14 days (mean $=8 \pm 1 \mathrm{SE}$ days). At the end of this period, these animals were studied using both clearance and micropuncture techniques. For comparison, 10 control rats were prepared and handled in an identical fashion except that they received continuous intravenous Ringer's infusions at rates amounting to no more than $1.5 \%$ body wt/day (less than $4 \mathrm{ml} /$ day) for periods of from 6 to 14 days (mean $=8 \pm 1$ day). On the morning of micropuncture study, control and chronically loaded animals were re-anesthetized, this time with intraperitoneal Inactin, sodium ethyl-(1-methyl-propyl)-malonylthio-urea, $100 \mathrm{mg} / \mathrm{kg}$, and prepared for micropuncture in the manner previously described $(5,6)$. Immediately upon insertion of the femoral arterial catheter, blood was obtained for repeat determination of hematocrit. Using this and the original (preinfusion) hematocrit, the percentage change in plasma volume was estimated (5). The rate of fluid infusion in chronically loaded rats was unaltered throughout the period of micropuncture and resulted in no consistent change in extracellular volume, as evidenced by the finding that systemic hematocrit changed, on average, by less than $2 \mathrm{vol} / 100 \mathrm{ml}$ from the period immediately after induction of anesthesia to the point of completion of the experiment. Beginning $60 \mathrm{~min}$ before study, an intravenous infusion of $10 \%$ inulin containing $p$-aminohippuric acid $(\mathrm{PAH})$ was begun at the rate of $0.02 \mathrm{ml} / \mathrm{min}$. This resulted in final plasma inulin and $\mathrm{PAH}$ concentrations of about 1.0 and $0.04 \mathrm{mg} / \mathrm{ml}$, respectively. Since a study of the renal effects of chronic Ringer's loading necessitated the use of an unpaired experimental design, therefore making impossible the use of the recollection micropuncture technique, a special effort was made to obtain tubule fluid samples only from ultimate or penultimate surface proximal convolutions in both the control and chronically loaded rats. 35 surface proximal tubules were studied in each of the two groups, and in each group 26 of the surface loops which were punctured were ultimate and 9 were penultimate in location. These late segments were identified by observing the passage of lissamine green dye which was injected rapidly $(0.04 \mathrm{ml}$ of a $5 \%$ solution $)$ into the left jugular vein catheter. After this $60 \mathrm{~min}$ equilibration period, exactly timed (1-2 min) samples of fluid were collected from each of several late proximal convolutions for the determination of flow rate and inulin concentration. For these collections, sharpened micropipettes with outer tip diameters of 8-12 $\mu \mathrm{m}$ were employed. From these measurements, single nephron GFR (SNGFR) and the absolute rate of tubule fluid reabsorption to the site of puncture were calculated, using equations previously described (6). Quantitative collections of tubule fluid were obtained using the technique of controlled suction previously validated for this laboratory (2). Mean femoral arterial pressure $(\overline{\mathrm{AP}})$ was measured by means of a transducer (model P23Db, Statham Instruments, Inc., Oxnard, Calif.) connected to a direct writing recorder (model 7712, Hewlett-Packard Co., Palo Alto, Calif.). Arterial blood and 2 to 8 timed urine collections were obtained for determination of arterial hematocrit, plasma potassium concentration, and plasma and urine inulin, $\mathrm{PAH}$, and sodium concentrations which permitted calculation of $\mathrm{C}_{\mathrm{IN}}, \mathrm{C}_{\mathrm{PAB}}$, and $\mathrm{U}_{\mathrm{Na}} \mathrm{V}$. In addition, simultaneous estimates of femoral arterial and efferent arteriolar plasma protein concentrations were obtained using recently described techniques $(6,7)$, and from these measurements, single nephron cortical filtration fractions (SNFF) were calculated (6). At the completion of each study both kidneys were weighed. Analytical methods and calculations employed in the present study have been described in detail elsewhere $(6,7)$.

Acute expansion in chronically loaded rats. In order to examine the effect of an acute, superimposed reduction in postglomerular vascular protein concentration on absolute rates of proximal tubule fluid reabsorption in chronically loaded rats, five additional chronically loaded rats (5-8 days) were studied, using clearance and micropuncture techniques as described above, before and after the acute infusion of $22 \mathrm{ml}$ of isotonic Ringer's (about $7 \%$ body wt) administered in a period of $1 \mathrm{hr}$. In addition, the renal extraction of $\mathrm{PAH}\left(\mathrm{E}_{\mathbf{P A H}}\right)$ was determined in three of these rats using collection techniques and analytical methods reported previously (5).

Results are expressed as means \pm 1 SE. Statistical tests of significance were performed using either the Student's $t$ test of the differences between unpaired groups (chronic control vs. chronic loading) or the $t$ test of the mean of paired differences (acute expansion study) (8). Difference were considered significant when $P<0.05$.

\section{RESULTS}

Chronic control vs. chronically loaded rats. Chronically loaded rats received continuous infusions of sodium, at rates averaging $11.5 \mu \mathrm{eq} / \mathrm{min}$, for periods of from 5 to 14 days. As shown in the upper half of Fig. 1, this resulted in an adaptive increase in $\mathrm{U}_{\mathrm{Na}} \mathrm{V}$ averaging 
from $1.6 \pm 0.3 \mu \mathrm{eq} / \mathrm{min}$, before, to $11.1 \pm 0.3 \mu \mathrm{eq} / \mathrm{min}$, during infusion. Of interest, attainment of this rate of excretion, which virtually matched the rate of infusion, took place within $200 \mathrm{~min}$ of the onset of infusion in all four rats and in as little time as $100 \mathrm{~min}$ in one rat. This achievement of a steady state of sodium balance was associated with a positive cumulative fluid balance ranging from 3.8 to $13.7 \mathrm{ml}$ or 1 to $4 \%$ body wt and averaging $2 \pm 0.7 \%$ body wt. Not unexpectedly, in view of this modest cumulative positive fluid balance, rats receiving chronic Ringer's loads differed little from chronic control rats with regard to changes in body weight, systemic hematocrit, and plasma protein concentration. Initial body weights were comparable in the chronic control and loaded groups, averaging $340 \pm 8.9$ and $330 \pm 11.9 \mathrm{~g}$, respectively; after chronic infusion, weights remained essentially unchanged, averaging 338 \pm 14.1 and $326 \pm 10.6 \mathrm{~g}$, respectively. ${ }^{2}$ Systemic hematocrit fell in seven of eight chronically loaded rats from an average of $45 \pm 0.4 \%$, before, to $40 \pm 1.2 \%$, after the period of infusion. $(P<0.025)$, corresponding to a mean increase in plasma volume of $22 \% .^{8}$ In contrast, in chronic control rats, hematocrit either remained unchanged or increased slightly, the overall change from $45 \pm 1.3 \%$, before, to $48 \pm 0.8 \%$ after the period of infusion, being statistically insignificant $(P>0.2)$. Systemic protein concentration (lower half, Fig. 1 and Tables $\mathrm{I}$ and II) after chronic infusion, averaged 6.0 $\pm 0.1 \mathrm{~g} / 100 \mathrm{ml}$ in control and $5.5 \pm 0.2 \mathrm{~g} / 100 \mathrm{ml}$ in loaded rats. The small average difference of $8 \%$ was significant $(P<0.05)$. During the period of micropuncture, $U_{\mathrm{Na}} \mathrm{V}$ by experimental (left) kidneys of chronically loaded rats uniformly exceeded corresponding values for $\mathrm{U}_{\mathrm{Na}} \mathrm{V}$ in control rats, averaging $3.17 \pm 0.60$ and $0.14 \pm 0.02 \mu \mathrm{eq} / \mathrm{min}$, respectively. Since, in the awake state, total $\mathrm{U}_{\mathrm{Na}} \mathrm{V}$ (the sum of $\mathrm{U}_{\mathrm{Na}} \mathrm{V}$ of both kidneys) in chronically loaded rats averaged $11.1 \mu \mathrm{eq} / \mathrm{min}$ (a value considerably more than twice $3.17 \mu \mathrm{eq} / \mathrm{min}$ ),

${ }^{2}$ Of interest, 10 other adult rats of comparable initial body weight, but which were subjected neither to chronic infusion nor jugular vein catheterization, exhibited a uniform tendency to gain weight during a similar period of time (4-13 days, mean $=7.2$ days). In these rats, weight gain ranged from 4.5 to $52.5 \mathrm{~g}$ and averaged $28 \pm 6 \mathrm{~g}$. Chronic catheterization, therefore, appeared to retard growth, in both chronic control and chronically loaded rats, an effect which probably relates, at least in part, to a decrease in caloric intake which was observed in both groups. Of additional interest, chronic loading did not result in any significant difference in kidney weight between groups. In eight control rats, left and right kidney weights averaged $1.37 \pm 0.1$ and $1.31 \pm 0.1 \mathrm{~g}$, respectively; weights of left and right kidneys of nine chronically loaded rats averaged 1.39 \pm 0.05 and $1.36 \pm 0.1 \mathrm{~g}$, respectively.

${ }^{3}$ For this calculation, we have assumed that circulating red cell mass remained constant throughout the period of chronic infusion.

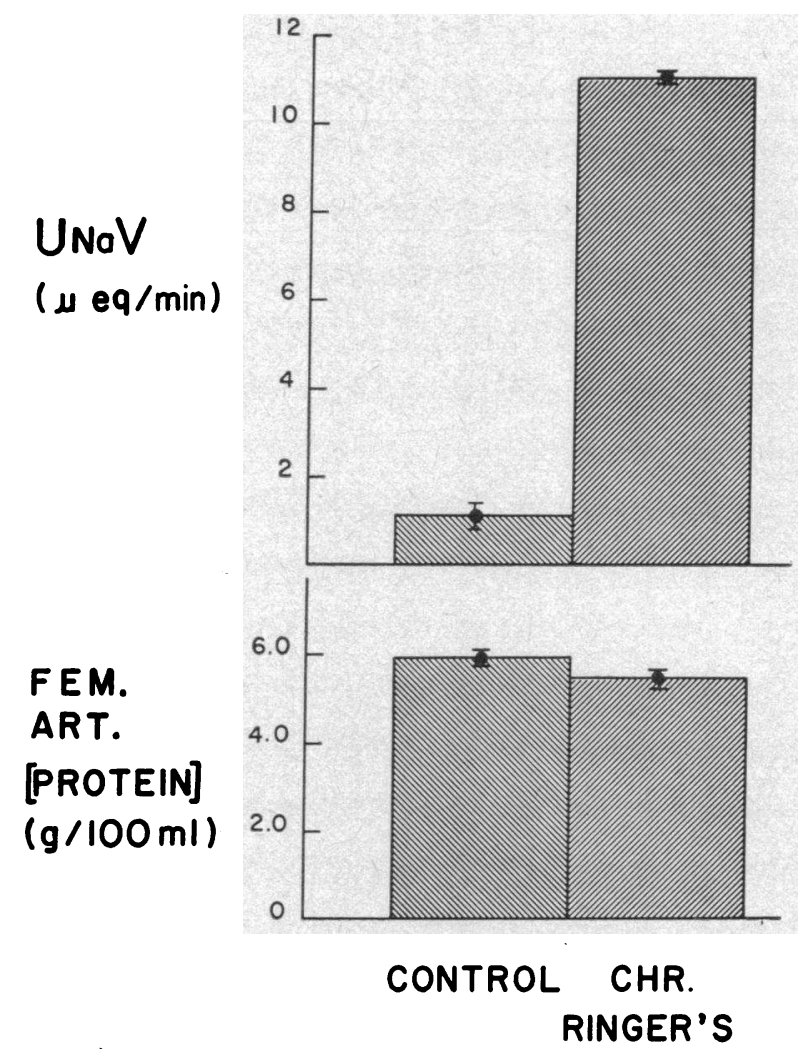

FIGURE 1 Comparison of $\mathrm{U}_{\mathrm{Na}} \mathrm{V}$ and femoral arterial protein concentration in control and chronically loaded rats. Bar heights indicate average values; brackets indicate \pm 1 SE.

it seems likely that total $\mathrm{U}_{\mathrm{Na}} \mathrm{V}$ was diminished in these rats during the period of micropuncture, an effect probably related to general anesthesia and surgery.

Shown in Tables I and II are results of a number of measurements of systemic, whole kidney and single nephron function in each group of rats. The ranges of $\overline{\mathrm{AP}}$ and $\mathrm{P}_{\mathrm{Na}}$ and $\mathrm{P}_{\mathrm{K}}$ concentrations were similar and overlapping in each group. $\mathrm{C}_{\mathrm{PAB}}$ was slightly, but significantly, greater in chronically loaded than in control rats, averaging $3.81 \pm 0.26$ and $3.16 \pm 0.08 \mathrm{ml} / \mathrm{min}$, respectively $(P<0.05)$. Although $\mathrm{E}_{\mathbf{P A B}}$ was not measured in these rats, values in three other chronically loaded rats were found to be very close to, and not greater than, values previously obtained in nonloaded rats from this laboratory (5). Therefore, the difference in $C_{\mathbf{P A}}$ between control and chronically loaded rats very likely reflects a corresponding difference in true renal plasma flow (RPF) between groups. Values for whole kidney GFR ( $\mathrm{C}_{\mathrm{IN}}$ ) are given in Fig. 2 (upper) and in Tables I and II. Although some overlap is evident between groups, $\mathrm{C}_{\mathrm{IN}}$ was significantly greater in chronically loaded rats $(P<0.005)$. The ratio $\mathrm{C}_{\mathrm{IN}} / \mathrm{C}_{\mathrm{PAB}}$ was 
TABLE I

Whole Kidney and Single Nephron Function in Control Rats.

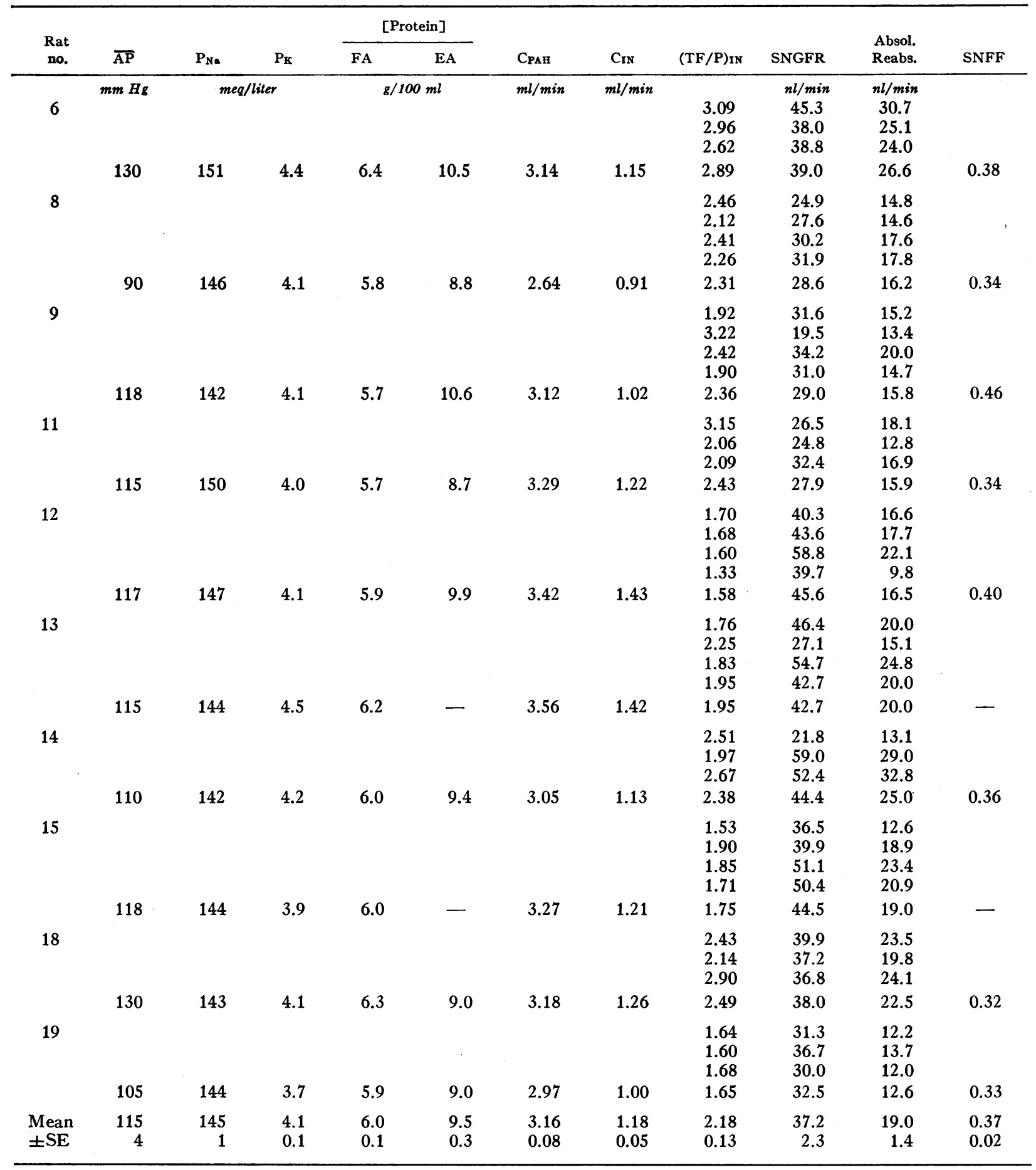

$\overline{\mathrm{AP}}$, mean arterial pressure; $\mathrm{P}_{\mathrm{Na}}$ plasma sodium concentration; $\mathrm{P}_{\mathrm{K}}$, plasma potassium concentration; [Protein]FA and EA, protein concentration in femoral arterial and efferent arteriolar blood plasma; (TF/P) IN, late proximal tubule fluid-toplasma inulin concentration ratio; SNGFR, single nephron GFR; Absol. Reabs., absolute rate of net fluid reabsorption to late proximal tubule; SNFF, single nephron filtration fraction.

24 T. M. Daugharty, I. F. Ueki, D. P. Nicholas, and B. M. Brenner 
TABLE II

Whole Kidney and Single Nephron Function in Chronically Loaded Rats

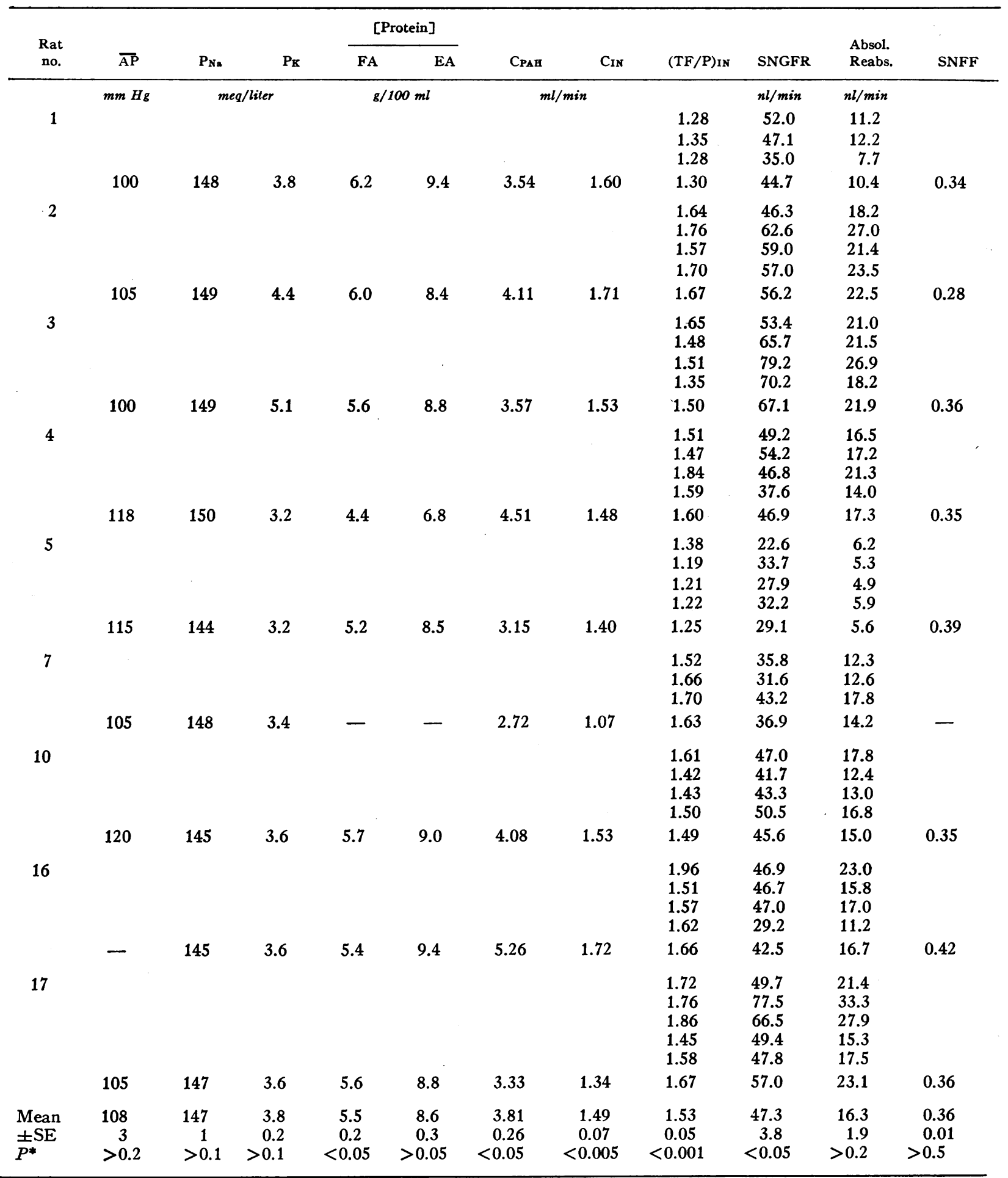

Consult the legend of Table I for abbreviations.

* Probability values; chronic control vs. chronically loaded groups. 


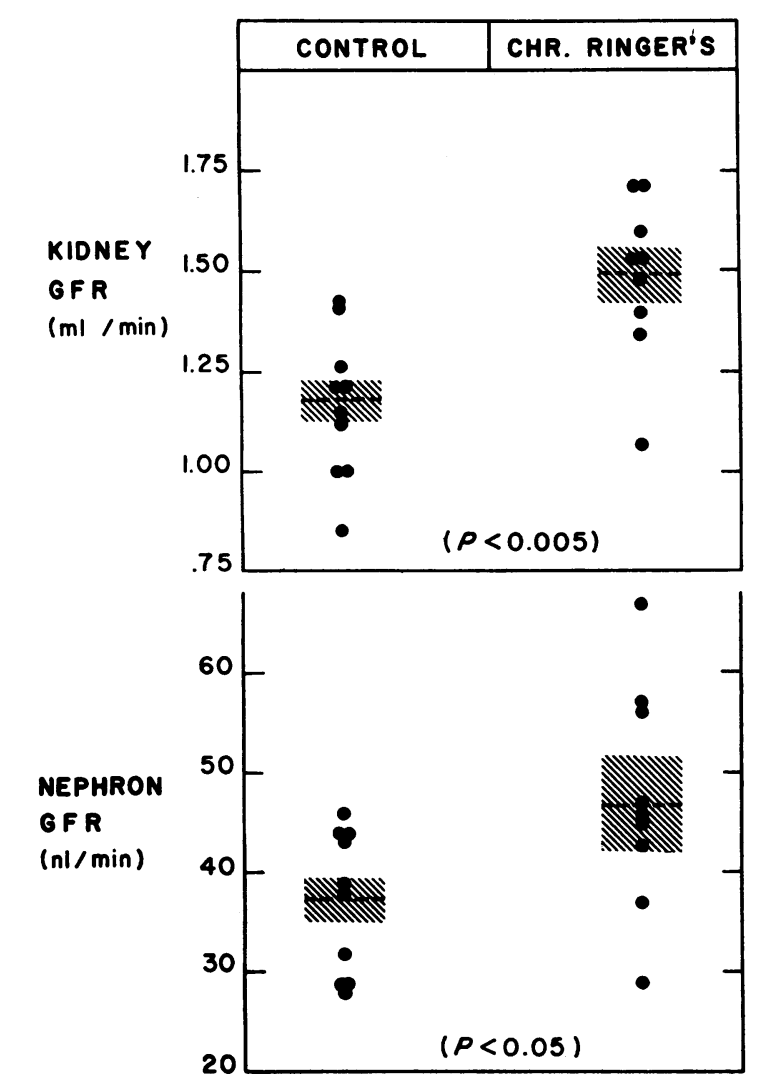

FIGURE 2 Comparison of whole kidney and SNGFR in chronic control and chronically loaded rats. For whole kidney GFR, each circle represents the mean of several whole kidney clearance determinations in each animal. For SNGFR, each circle represents the mean of values obtained from several tubules in each animal. Hatched areas indicate $\pm 1 \mathrm{SE}$.

essentially the same in control and chronically loaded rats, averaging $0.37 \pm 0.01$ and $0.40 \pm 0.02$, respectively $(P>0.1)$. The estimated filtered load of sodium ( $\mathrm{C}_{\mathrm{IN}}$ $\left.\times \mathrm{P}_{\mathrm{Na}}\right)$ averaged $171 \mu \mathrm{eq} / \mathrm{min}$ in chronic control and $219 \mu \mathrm{eq} / \mathrm{min}$ in chronically loaded rats $(P<0.005)$. This difference between mean values, $48 \mu \mathrm{eq} / \mathrm{min}$ per experimental kidney, is quantitatively more than adequate to account for the increment in $\mathrm{U}_{\mathrm{Na}} \mathrm{V}$ observed in the awake state.

As shown in the upper half of Fig. 3, the flow rate of fluid to the late proximal tubule tended to be higher in chronically loaded than in control rats, averaging $31.1 \pm 2.3$ and $18.4 \pm 1.9 \mathrm{nl} / \mathrm{min}$, respectively $(P<0.001)$. As shown in Fig. 3 (lower), mean late proximal (TF/ $P)_{\text {IN }}$ ratios in each rat were nearly always lower in the chronically loaded group than in controls, averaging $1.53 \pm 0.05$ and $2.18 \pm 0.13$, respectively $(P<0.001)$. Fractional proximal fluid reabsorption in these groups therefore averaged $0.34 \pm 0.02$ and $0.52 \pm 0.03$, respec- tively. SNGFR, shown in the lower half of Fig. 2, was significantly higher in the chronically loaded group, averaging $47.3 \pm 3.8$, as compared with $37.2 \pm 2.3 \mathrm{nl} / \mathrm{min}$ for controls $(P<0.05)$. Mean percentage differences in whole kidney and single nephron filtration rates between the two groups were similar, averaging 26 and $21 \%$, respectively. Redistribution of whole kidney GFR to the superficial cortex, therefore, does not appear to account for the observed large difference in $\mathrm{U}_{\mathrm{N}_{\mathrm{a}} \mathrm{V}}$ between groups. As shown in Fig. 4 (upper), absolute proximal reabsorption rates for rats in each group tended to overlap, averaging $19.0 \pm 1.4$ and $16.3 \pm 1.9$ $\mathrm{nl} / \mathrm{min}$ in control and chronically loaded rats, respectively. This difference was not significant $(P>0.2)$. As shown in Tables I and II and Fig. 4 (lower), the difference in efferent arteriolar protein concentration which accompanied the small and statistically insignificant difference in absolute proximal reabsorption was likewise small and insignificant, averaging $9.5 \pm 0.3$ and $8.6 \pm 0.3 \mathrm{~g} / 100 \mathrm{ml}$ in control and chronically loaded rats, respectively $(P>0.05)$. Single nephron filtration fraction, shown in Tables I and II, was essentially the same

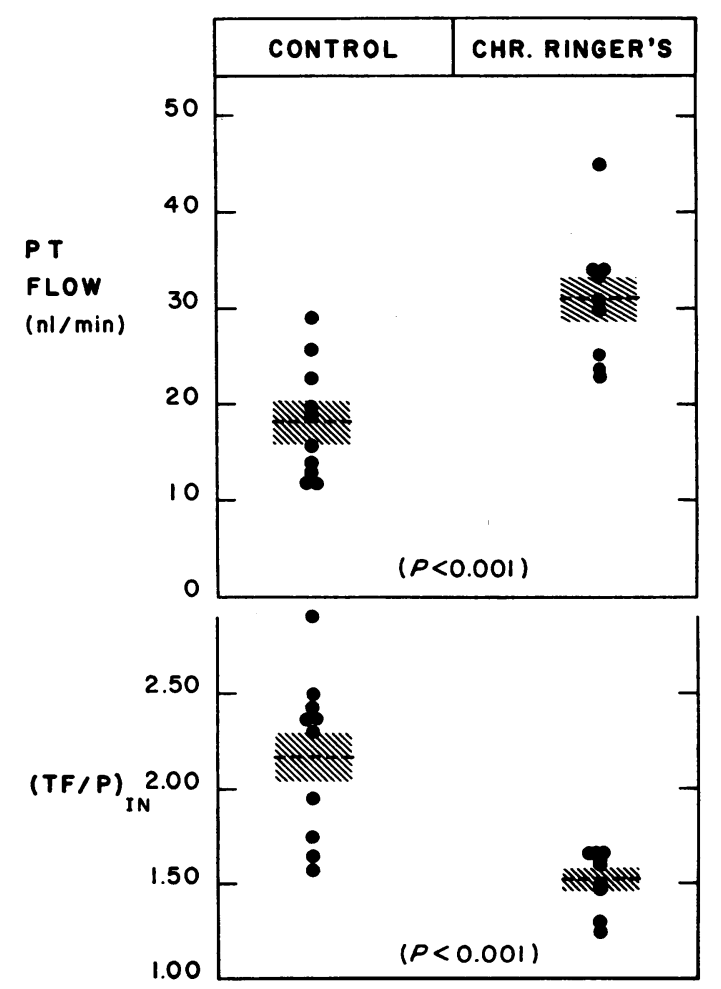

Figure 3 Comparison of the flow rate of fluid to the late proximal tubule (PT) and (TF/P) IN in chronic control and chronically loaded rats. Each solid circle represents the mean of values obtained from several tubules in each animal. Hatched areas indicate $\pm 1 \mathrm{SE}$. 
in control and loaded rats, averaging $0.37 \pm 0.02$ and $0.36 \pm 0.01$, respectively $(P>0.5)$.

Acute expansion in chronically loaded rats. Before acute expansion in these five chronically loaded rats, $\overline{\mathrm{AP}}$ averaged $113 \pm 9 \mathrm{~mm} \mathrm{Hg}$, systemic hematocrit 40 $\pm 1.0 \%$ and femoral arterial protein concentration, 5.3 $\pm 0.2 \mathrm{~g} / 100 \mathrm{ml}$. EPAB, measured in three of these rats, equaled $0.87,0.84$, and 0.80 . A summary of individual and mean values for $\mathrm{C}_{\mathrm{IN}}$ and several measures of single nephron function are given in Table III.

Superimposition of an acute Ringer's load resulted in uniform reductions in systemic plasma protein concentration, on average, to $4.6 \pm 0.2 \mathrm{~g} / 100 \mathrm{ml}$. $\mathrm{C}_{\mathrm{IN}}$ increased in four of five rats, on average by $21 \%$. Mean flow rates of fluid to the late proximal tubule increased in each rat from an average of $32.3 \pm 1.9$ to $48.3 \pm 2.9$ $\mathrm{nl} / \mathrm{min}(P<0.005)$. Mean $(\mathrm{TF} / \mathrm{P})_{\text {Is }}$ ratios (upper half, Fig. 5) fell uniformly after acute Ringer's loading, on average from $1.72 \pm 0.09$ to $1.33 \pm 0.06(P<0.001)$. Proximal fractional reabsorption therefore declined, on average, from $0.42 \pm 0.03$ to $0.23 \pm 0.03 \quad(P<0.001)$. SNGFR increased in four of five rats, on average, from $54.6 \pm 1.9$ to $63.3 \pm 3.2 \mathrm{nl} / \mathrm{min}(P<0.05)$. Accordingly, as shown in Fig. 5 (lower) absolute proximal reabsorption was uniformly depressed, averaging $22.3 \pm 1.8$ $\mathrm{nl} / \mathrm{min}$, before, and $15.0 \pm 2.4 \mathrm{nl} / \mathrm{min}$, after infusion $(P$

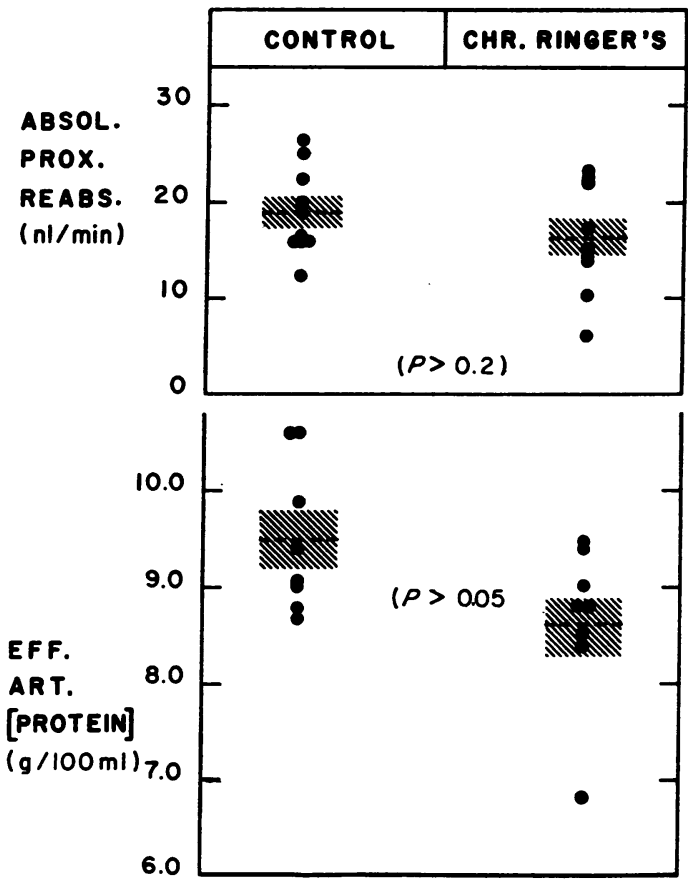

FIGURE 4 Comparison of late proximal absolute reabsorption and efferent arteriolar [protein] in chronic control and chronically loaded rats. Representation is the same as in Fig. 3.

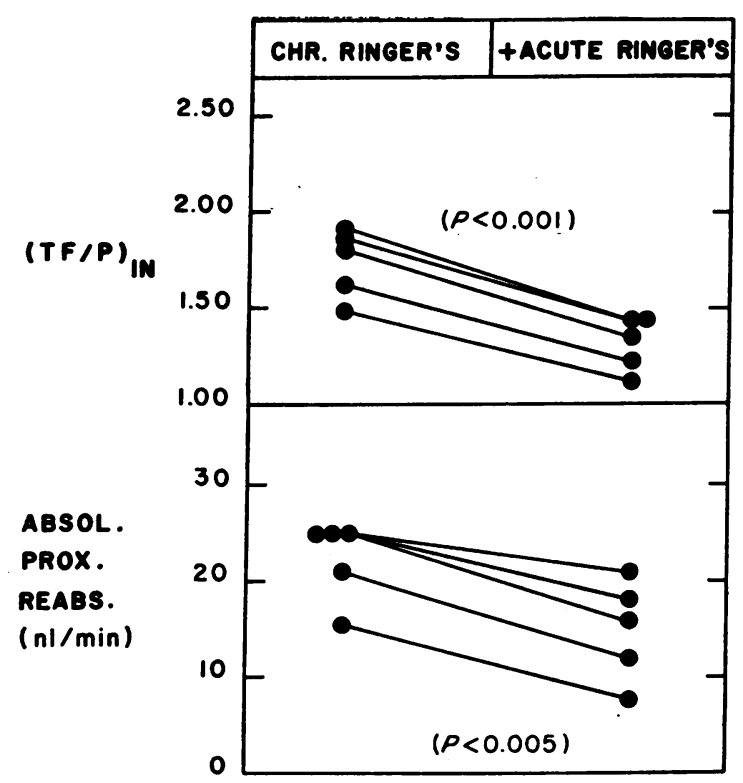

FIGURE 5 Effects of acute Ringer's load on late proximal $(\mathrm{TF} / \mathrm{P})_{\mathrm{IN}}$ and absolute reabsorption in chronically Ringer's loaded rats. Each circle represents the mean of values obtained from several tubules in each rat. Lines connect mean values from the same rat.

$<0.005)$. As shown in Table 1II, this fall in absolute proximal reabsorption was accompanied by a uniform fall in efferent arteriolar protein concentration, from an average of $8.6 \pm 0.3$ to $7.3 \pm 0.2 \mathrm{~g} / 100 \mathrm{ml}(P<0.005)$.

\section{DISCUSSION}

Recent studies from this laboratory have yielded evidence to indicate that the natriuresis which accompanies acute Ringer's loading in the rat is attended by marked expansion of plasma volume and corresponding dilution of pre- and postglomerular plasma protein concentration $(2,3,5)$. In contrast, the results of the present study demonstrate that the natriuresis of chronic Ringer's loading is associated with only mild expansion of plasma volume and little reduction in pre- and postglomerular plasma protein concentration. The present study identifies another seemingly important quantitative difference between acute and chronic Ringer's loading in the rat, namely the mechanism(s) governing the measured increases in rates of delivery of proximal tubule fluid to more distal portions of the nephron. Whereas in acute Ringer's loading this enhanced distal delivery derives nearly equally from enhanced filtration and diminished absolute proximal reabsorption $(2,3,5)$ after chronic Ringer's loading, the quantitatively similar increment in distal delivery appears to be accounted for primarily by enhanced filtration and only to a small extent by inhibition of reabsorption. A possible explanation for this latter 
TABLE III

Effects of Acute Ringer's Loads on Whole Kidney and Single Nephron Function in Chronically Loaded Rats

\begin{tabular}{|c|c|c|c|c|c|c|c|c|c|c|c|c|}
\hline \multirow{3}{*}{$\begin{array}{c}\text { Rat } \\
\text { no. }\end{array}$} & \multicolumn{6}{|c|}{ Chronically Ringer's loaded } & \multicolumn{6}{|c|}{ Superimposed acute Ringer's load } \\
\hline & \multicolumn{2}{|c|}{ [Protein] } & \multirow[b]{2}{*}{ Cin } & \multirow[b]{2}{*}{$(\mathrm{TF} / \mathrm{P})_{\mathrm{IN}}$} & \multirow[b]{2}{*}{ SNGFR } & \multirow{2}{*}{$\begin{array}{l}\text { Absol. } \\
\text { Reabs. }\end{array}$} & \multicolumn{2}{|c|}{ [Protein] } & \multirow[b]{2}{*}{ Cin } & \multirow[b]{2}{*}{$(\mathrm{TF} / \mathrm{P})_{\mathrm{IN}}$} & \multirow[b]{2}{*}{ SNGFR } & \multirow{2}{*}{$\begin{array}{l}\text { Absol. } \\
\text { Reabs. }\end{array}$} \\
\hline & FA & EA & & & & & FA & EA & & & & \\
\hline \multirow{6}{*}{20} & \multicolumn{2}{|c|}{$\mathrm{g} / 100 \mathrm{ml}$} & $\operatorname{ml} / \min$ & & $n l / \min$ & $n l / m i n$ & \multicolumn{2}{|c|}{$\mathrm{g} / 100 \mathrm{ml}$} & $m l / m i n$ & & $n l / \min$ & $n l / m i n$ \\
\hline & & & & 1.60 & 54.1 & 20.3 & & & & & & \\
\hline & & & & 1.52 & 51.6 & 17.6 & & & & & & \\
\hline & & & & 1.38 & 48.9 & 13.5 & & & & 1.17 & 50.9 & 7.3 \\
\hline & & & & 1.37 & 40.4 & 11.0 & & & & 1.14 & 65.7 & 8.0 \\
\hline & 5.0 & 7.6 & 1.61 & 1.47 & 48.7 & 15.6 & 4.5 & 6.9 & 1.61 & 1.16 & 58.3 & 7.7 \\
\hline \multirow[t]{5}{*}{21} & & & & 1.62 & 68.9 & 26.5 & & & & & & \\
\hline & & & & $\begin{array}{l}1.28 \\
1.66\end{array}$ & $\begin{array}{l}60.5 \\
63.6\end{array}$ & $\begin{array}{l}13.1 \\
25.2\end{array}$ & & & & $\begin{array}{l}1.41 \\
1.12\end{array}$ & $\begin{array}{l}75.6 \\
68.5\end{array}$ & $\begin{array}{r}21.8 \\
7.4\end{array}$ \\
\hline & & & & 1.85 & 50.4 & 23.2 & & & & 1.26 & 56.1 & 11.5 \\
\hline & & & & 1.45 & 56.4 & 17.5 & & & & 1.11 & 61.9 & 6.23 \\
\hline & 5.8 & 9.2 & 1.97 & 1.57 & 60.0 & 21.1 & 5.1 & 7.7 & 2.20 & 1.22 & 65.5 & 11.7 \\
\hline \multirow[t]{5}{*}{22} & & & & & & & & & & 1.43 & 46.1 & 13.8 \\
\hline & & & & 2.05 & 56.2 & 28.8 & & & & 1.56 & 63.9 & 22.8 \\
\hline & & & & 1.68 & 49.1 & 19.9 & & & & 1.37 & 52.0 & 14.2 \\
\hline & & & & 2.03 & 54.4 & 27.6 & & & & 1.39 & 51.6 & 14.4 \\
\hline & 5.8 & 9.4 & 1.62 & 1.92 & 53.2 & 25.4 & 5.1 & 7.7 & 1.88 & 1.44 & 53.4 & 16.3 \\
\hline \multirow[t]{5}{*}{23} & & & & 1.93 & 48.4 & 23.3 & & & & & & \\
\hline & & & & 1.88 & 59.2 & 27.7 & & & & 1.57 & 72.6 & 26.3 \\
\hline & & & & 2.09 & 60.6 & 31.6 & & & & 1.58 & 70.1 & 25.7 \\
\hline & & & & 1.53 & 45.6 & 15.7 & & & & 1.22 & 68.1 & 12.3 \\
\hline & 4.8 & 8.2 & 1.83 & 1.86 & 53.5 & 24.6 & 4.2 & 7.1 & 2.23 & 1.46 & 70.2 & 21.4 \\
\hline \multirow[t]{5}{*}{24} & & & & 2.30 & 56.8 & 32.1 & & & & & & \\
\hline & & & & 1.90 & 67.0 & 31.7 & & & & 1.21 & 59.0 & 10.2 \\
\hline & & & & 1.52 & 51.6 & 17.6 & & & & 1.33 & 75.4 & 18.7 \\
\hline & & & & 1.49 & 54.6 & 17.9 & & & & 1.51 & 72.7 & 24.6 \\
\hline & 4.8 & 8.8 & 1.92 & 1.80 & 57.5 & 24.8 & 4.2 & 7.1 & 2.76 & 1.35 & 69.0 & 17.9 \\
\hline Mean & 5.3 & 8.6 & 1.79 & 1.72 & 54.6 & 22.3 & 4.6 & 7.3 & 2.14 & 1.33 & 63.3 & 15.0 \\
\hline$\pm \mathrm{SE}$ & 0.2 & 0.3 & 0.07 & 0.09 & 1.9 & 1.8 & 0.2 & 0.2 & 0.19 & 0.06 & 3.2 & 2.4 \\
\hline$P$ & & & & & & & $<0.001$ & $<0.005$ & $>0.05$ & $<0.001$ & $<0.05$ & $<0.005$ \\
\hline
\end{tabular}

Consult Table I for abbreviations.

difference is provided by the present study. Since the inhibition in absolute proximal reabsorption observed in response to acute Ringer's loading in the rat has been shown to be casually mediated, at least in part, by the accompanying fall in postglomerular vascular protein concentration (3), the apparent failure of chronic Ringer's loading to significantly depress absolute proximal reabsorption may have been due to a similar lack of any significant reduction in postglomerular protein concentration. In support of this view is the finding that when postglomerular protein concentration of chronically loaded rats is acutely reduced by superimposition of a large Ringer's load, there takes place a significant and corresponding decline in absolute proximal reabsorption. Thus the present findings suggest that the lack of significant inhibition in absolute proximal reabsorption in response to chronic Ringer's loading may have been the result of the fact that postglomerular plasma protein concentration was little altered by chronic infusion. Support for this view is provided by the results of recent studies of the effects of acute iso-oncotic plasma loading on absolute proximal reabsorption in the rat (5). As in the present study, postglomerular protein concentration was not significantly altered from pre-expansion 
levels, and, in accord with the finding during chronic Ringer's loading, absolute proximal reabsorption likewise remained unchanged. The increment in distal delivery resulting from acute plasma loading (5) was similar to that observed in the present study, and, as in the present study, was found to be accounted for nearly entirely by the measured increments in SNGFR. Accordingly, since absolute proximal reabsorption remains relatively constant in response to acute plasma loading or chronic Ringer's loading proximal fractional reabsorption varies inversely with, and distal delivery directly with, filtered load. Thus, the glomerulotubular balance of sodium and water by the rat proximal convoluted tubule, a more or less proportional balance between filtration and reabsorption, is markedly disrupted by these states of acute plasma and chronic Ringer's loading. Common to both states is the finding that a major determinant of reabsorption extrinsic to the proximal tubule, namely postglomerular vascular plasma protein concentration $(1,3,5-7,9-14)$, was essentially unchanged by these volume-loading procedures. These in vivo observations during acute plasma and chronic Ringer's loading, which argue for little control of absolute proximal reabsorption by mechanisms intrinsic to the epithelial cylinder of the proximal convoluted tubule, are in close agreement with recent tubule microperfusion studies $(1,15-18)$ which demonstrate that if the environment external to the perfused proximal tubule, and in particular peritubule colloid-osmotic pressure, is deliberately unperturbed, absolute proximal reabsorption remains relatively constant so that proximal fractional reabsorption varies inversely with perfusion rate.

The difference in the degree of reduction of plasma protein concentration resulting from acute as compared with chronic Ringer's loading, therefore, appears to account, at least in part, for the observed differences in effects on absolute proximal reabsorption. The large positive fluid balance and resulting progressive dilution which have been demonstrated to occur in acutely loaded rats may be, at least in part, the result of $(a)$ the more rapid rate of infusion in the former group (administration of volumes equal to $25-35 \mathrm{ml}$ in a $90 \mathrm{~min}$ period in acutely loaded rats, as compared with approximately 6 $\mathrm{ml} / 90 \mathrm{~min}$ in chronically loaded rats) and (b) the fact that acutely loaded rats receive their infusions after induction of general anesthesia and completion of abdominal surgery and are, therefore, subject to the wellknown anti-natriuretic effects which accompany these procedures (19-22).

The present study demonstrates that chronic Ringer's loading is associated with a substantial increase in the filtered load of sodium which is quantitatively more than adequate to account for the accompanying natriuresis. Since, for the superficial cortex at least, the increment in filtration was reflected virtually quantitatively by the increase in the flow rate of fluid to and beyond the late proximal tubule, the present results suggest that increased distal sodium delivery may have been adequate to account for the natriuresis of chronic Ringer's loading. Moreover, since the increment in the delivery of fluid beyond the proximal tubule very likely exceeds the increment in sodium excretion, these findings suggest that absolute sodium reabsorption was increased in segments beyond the proximal tubule.

Of interest in the present study is the finding that SNGFR was higher, on average, in experimental than in control rats whereas SNFF was essentially the same. Accordingly, the rise in SNGFR must have been accompanied by a more-or-less proportional rise in the rate of glomerular capillary plasma flow. While the possibility cannot be excluded that this rise in SNGFR resulted from a rise in glomerular capillary hydrostatic pressure, an alternate explanation, and one in keeping with recent observations from this laboratory $(23,24)$ is that this increase in filtration rate occurred as a flowdependent consequence of the increase in glomerular capillary plasma flow. These recent observations in mutant Wistar rats demonstrate that a state of filtration pressure equilibrium, characterized by essentially zero net ultrafiltration pressure, is achieved before the efferent arteriolar end of the glomerular capillary, not only at normal (23) but also at twice-normal rates of glomerular capillary plasma flow (24). In these latter studies, filtration pressure equilibrium was achieved at these high rates of plasma flow in the absence of increases in glomerular capillary hydrostatic pressure or measured decreases in afferent arteriolar colloid osmotic, or Bowman's space hydrostatic pressures. Thus, these findings in mutant Wistar rats demonstrate that for outer cortical glomeruli, at least, filtration rate varies as a direct function of glomerular capillary plasma flow. Unlike these mutant Wistar rats, Sprague-Dawley rats, such as those employed in the present study, seldom possess accessible surface glomeruli. A systematic assessment of the transcapillary forces governing ultrafiltration in this latter breed has therefore not yet been possible. Recently, however, we have encountered a group of Sprague-Dawley rats, each possessing one or more surface glomeruli and in these have been able to estimate transcapillary hydrostatic pressures and end-glomerular capillary net ultrafiltration pressure (unpublished observations). Results thus far reveal that filtration pressure equilibrium is also a characteristic of outer cortical glomeruli in this strain of rats during normal hydropenia. Accordingly, the strong possibility exists that glomerular filtration in cortical nephrons of this strain also varies directly with, and in proportion to, glomerular plasma flow. In view of these observations, and the present finding that SNFF 
was essentially the same in control and experimental rats at different values for SNGFR, we consider it likely that the greater SNGFR observed in experimental rats resulted as a flow-dependent consequence of the greater rate of glomerular plasma flow in these rats. The rise in glomerular plasma flow, in turn, may have resulted from a fall in blood viscosity due to hemodilution.

To date only one other micropuncture study of the effects of chronic intravenous fluid infusion on the renal handling of sodium in unanesthetized rats has been reported (25). Kuschinsky, Wahl, Wunderlich, and Thurau infused saline into unrestrained rats in amounts equal to about $70 \%$ body wt/day for periods of from 9 to 17 days and compared the results obtained in these rats with values from a separate group of normal hydropenic rats subjected neither to chronic venous catheterization nor sham infusion. These workers observed a significantly lower value for mean proximal fractional reabsorption in experimental rats relative to nonshaminfused controls, an effect, as in the present study, due solely to a greater filtered load and not to inhibition of absolute proximal reabsorption. In addition, systemic hematocrit and plasma protein concentration were found to be lower in experimental than in control rats, on average, by 18 and $39 \%$, respectively, leading the authors to conclude that variations in peritubular protein concentration cannot influence proximal fractional reabsorption under physiological conditions. Although the aforementioned differences in SNGFR, fractional reabsorption, and systemic hematocrit and protein concentration could have been due, as the authors suggest, to effects of chronic saline loading, the possibility not excluded by their use of nonsham-treated controls is that these differences were the result, entirely or in part. of factors related to chronic venous catheterization. The need for adequate (sham-treated) controls in the study by Kuschinsky et al. (25) is underscored by the statement of the authors that a number of chronically infused rats were excluded from consideration because of evidence of systemic infection, presumably acquired as a result of chronic venous catheterization. The possibility exists therefore that differences attributed by the authors to effects of chronic saline loading could also have been due to undetected sepsis. Thus, for example, the $18 \%$ lower hematocrit observed in experimental rats could just as likely have been due to the altered erythrokinetics of infection as to hemodilution. In support of the former possibility was the finding of no significant weight gain and a proportionately greater decline in systemic protein concentration (39\%) than hematocrit. Given this profound degree of hypoproteinemia without weight gain, a possibility not excluded in their study is that intravascular volume depletion may actually have occurred in experimental rats, a stimulus recently shown to in- crease cortical nephron filtration fraction (26) and favor enhanced rates of absolute proximal reabsorption (2628).

In summary, the present study demonstrates that the natriuresis of chronic Ringer's loading, like acute Ringer's loading, is accompanied by a large fall in proximal fractional reabsorption, and a large increase in the delivery of tubule fluid to more distal segments of the nephron. Unlike acute Ringer's loading, however, which produces these effects both by increasing GFR and decreasing absolute proximal reabsorption, chronic Ringer's loading increases distal delivery primarily as a result of increasing GFR. The present study also provides evidence to indicate that this difference between the proximal reabsorptive effects of acute and chronic Ringer's loading may be due, at least in part, to a corresponding difference in their effects on postglomerular vascular plasma protein concentration. The more marked degree of plasma dilution observed in response to acute Ringer's loading is viewed as being the consequence of a correspondingly greater degree of fluid retention. Finally, the present studies provide additional evidence to support the view that postglomerular vascular protein concentration is an important determinant of absolute reabsorption by the renal proximal tubule of the rat.

\section{ACKNOWLEDGMENTS}

The authors are grateful to Carolyn Wong for technical assistance and Karen L. Anderson for secretarial help.

Support for these studies was provided by the Veterans Administration (30/101.790 and 01/1073.1) and National Institutes of Health (AM 13888).

\section{REFERENCES}

1. Sonnenberg, H., and S. Solomon. 1969. Mechanism of natriuresis following intravascular and extracellular volume expansion. Can. J. Physiol. Pharmacol. 47: 153.

2. Brenner, B. M., T. M. Daugharty, I. F. Ueki, and J. L. Troy. 1971. Quantitative assessment of proximal tubule function in single nephrons of the rat kidney. Am.J. Physiol. 220: 2058.

3. Brenner, B. M., J. L. Troy, and T. M. Daugharty. 1971. On the mechanism of inhibition in fluid reabsorption by the renal proximal tubule of the volume-expanded rat. J. Clin. Invest. 50: 1596.

4. Bartoli, E., and L. E. Earley. 1971. The relative contributions of reabsorptive rate and redistributed nephron filtration rate to changes in proximal tubular fractional reabsorption during acute saline infusion and aortic constriction in the rat. J. Clin. Invest. 50: 2191.

5. Daugharty, T. M., I. F. Ueki, D. P. Nicholas, and B. M. Brenner. 1972. Comparative renal effects of isoncotic and colloid-free volume expansion in the rat. $\mathrm{Am}$. J. Physiol. 222: 225.

6. Brenner, B. M., and J. H. Galla. 1971. Influence of postglomerular hematocrit and protein concentration on rat nephron fluid transfer. Am. J. Physiol. 220: 148.

7. Brenner, B. M., K. H. Falchuk, R. I. Keimowitz, and R. W. Berliner. 1969. The relationship between peri- 
tubular capillary protein concentration and fluid reabsorption by the renal proximal tubule. J. Clin. Invest. 48: 1519.

8. Bailey, N. T. J. 1959. Statistical Methods in Biology. John Wiley \& Sons, Inc., New York.

9. Spitzer, A., and E. E. Windhager. 1970. Effect of peritubular oncotic pressure changes on proximal tubular fluid reabsorption. Am. J. Physiol. 218: 1188 .

10. Brenner, B. M., and J. L. Troy. 1971. Postglomerular vascular protein concentration: evidence for a causal role in governing fluid reabsorption and glomerulotubular balance by the renal proximal tubule. J. Clin. Invest. $50: 336$.

11. Falchuk, K. H., B. M. Brenner, M. Tadokoro, and R. W. Berliner. 1971. Oncotic and hydrostatic pressures in peritubular capillaries and fluid reabsorption by proximal tubule. Am. J. Physiol. 220: 1427.

12. Weinman, E. J., M. Kashgarian, and J. P. Hayslett. 1971. Role of peritubular protein concentration in sodium reabsorption. Am. J. Physiol. 221: 1521.

13. Grantham, J. J., P. Qualizza, and L. W. Welling. 1971. Influence of serum proteins on net fluid absorption of isolated proximal renal tubules. Abstracts of the American Society of Nephrology. 5: 28.

14. Imai, M., and J. P. Kokko. 1972. Effect of peritubular protein concentration on reabsorption of sodium and water in isolated perfused proximal tubules. J. Clin. Invest. $51: 314$.

15. Burg, M. B., and J. Orloff. 1968. Control of fluid absorption in the renal proximal tubule. J. Clin. Invest. 47: 2016

16. Morgan, T., and R. W. Berliner. 1969. In vivo perfusion of proximal tubules of the rat: glomerulotubular balance. Am. J. Physiol. 217 : 992.

17. Morel, F., and Y. Murayama. 1970. Simultaneous measurement of unidirectional and net sodium fluxes in microperfused rat proximal tubules. Pfluegers Arch. Gesamte Physiol. Menschen Tiere. 320: 1.

18. Buentig, W. E., and L. E. Earley. 1971. Demonstration of independent roles of proximal tubular reabsorption and intratubular load in the phenomenon of glomerulotubular balance during aortic constriction in the rat. J. Clin. Invest. $50: 77$.

19. Habif, D. V., E. M. Papper, H. F. Fitzpatrick, P. Lawrence, S. McC. Smythe, and S. E. Bradley. 1951. The renal and hepatic blood flow, glomerular filtration rate, and urinary output of electrolytes during cyclopropane, ether, and thiopental anesthesia, operation, and the immediate postoperative period. Surgery. 30: 241.

20. Papper, S., and E. M. Papper. 1964. The effects of preanesthetic, anesthetic and postoperative drugs on renal function. Clin. Pharmacol. Ther. 5: 205.

21. Deutsch, S., M. Goldberg, G. W. Stephen, and W. H. Wu. 1966. Effects of halothane anesthesia on renal function in normal man. Anesthesiology. 27: 793.

22. Deutsch, S. 1971. Anesthetic effects on kidney. Kidney. 4: 1 .

23. Brenner, B. M., J. L. Troy, and T. M. Daugharty. 1971. The dynamics of glomerular ultrafiltration in the rat. J. Clin. Invest. 50: 1776.

24. Brenner, B. M., J. L. Troy, T. M. Daugharty, W. M. Deen, and C. R. Robertson. 1972. Dynamics of glomerular ultrafiltration in the rat. II. Plasma-flow dependence of GFR. Am. J. Physiol. 223: 1184:

25. Kuschinsky, W., M. Wahl, P. Wunderlich, and K. Thurau. 1970. Different correlations between plasma protein concentration and proximal fractional reabsorption in the rat during acute and chronic saline infusion. Pfluegers Arch. Gesamte Physiol. Menschen Tiere. 321: 102.

26. Weinman, E. J., M. Kashgarian, and J. P. Hayslett. 1971. Role of peritubular protein concentration in sodium reabsorption. Am. J. Physiol. 221: 1521.

27. Brenner, B. M., and R. W. Berliner. 1969. Relationship between extracellular volume and fluid reabsorption by the rat nephron. Am. J. Physiol. 217: 6.

28. Weiner, M. W., E. J. Weinman, M. Kashgarian, and J. P. Hayslett. 1971. Accelerated reabsorption in the proximal tubule produced by volume depletion. J. Clin. Invest. 50: 1379. 